\title{
Comparison of techniques for determining the nutritional carrying capacity for white-tailed deer
}

\author{
THOMAS C. MCCALL, ROBERT D. BROWN, AND LOUIS C. BENDER
}

\begin{abstract}
Authors are planning biologist, Washington Department of Fish and Wildlife, Olympia, Wash. 98501; department head, Department of Wildlife and Fisheries Science, Texas A\&M University, College Station, Tex. 77843; and area wildlife biologist, Washington Department of Fish and Wildlife, Vancouver, Wash. 98663. At the time of the research, the senior author was research assistant and second author was professor, Caesar Kleberg Wildlife Research Institute, Texas A\&M University, Kingsville, Tex. 78363.
\end{abstract}

\section{Abstract}

Estimates of carrying capacity for herbivores are useful for determining the relative value of different ranges. We compared 6 estimates of nutritional carrying capacity for white-tailed deer (Odocoileus virginianus L.): digestible energy consumed by tame deer, and 5 methods using forage supplies of dry matter, digestible energy, digestible nitrogen, dry matter*digestible energy, and dry matter*digestible nitrogen in two 1-ha enclosures of different shrub plant communities in southern Texas. For the north enclosure, carrying capacity estimates $(90 \% \mathrm{CI})$ were 3.65 $(\mathrm{CI}=3.61-3.69), 4.5(\mathrm{CI}=3.7-5.3), 9.4(\mathrm{CI}=7.3-11.5), 15.2(\mathrm{CI}=$ 11.6-18.8), 3.5 (CI = 2.7-4.3), and $3.5(\mathrm{CI}=2.7-4.3)$ deer $\mathrm{ha}^{-1} 58$ days $^{-1}$ for the digestible energy tame deer, dry matter, digestible energy, digestible nitrogen, dry matter*digestible energy, and dry matter*digestible nitrogen techniques, respectively. Corresponding estimates for the south enclosure were 2.6 (CI = 2.5-2.7), $3.5(\mathrm{CI}=3.2-3.9), 6.8(\mathrm{CI}=6.0-7.6), 10.1(\mathrm{CI}=$ 8.8-11.3), 2.1 (CI = 1.8-2.6), and $2.8(C I=2.4-3.1)$. Some methods for estimating carrying capacity provided different absolute estimates, but all produced similar relative estimates between enclosures. Similar relative results between enclosures suggests any of the methods can be used to determine the relative nutritional quality of plant communities. However, the dry matterbased technique was less expensive than the other techniques; therefore, there is no need to use more costly techniques for determining the relative stocking rates for white-tailed deer, unless forage quality differs greatly among plant communities.

Key Words: carrying capacity, digestible energy, digestible nitrogen, Odocoileus virginianus L., southern Texas.

Estimates of nutritional carrying capacity are useful for comparing the ability of different ranges to support wildlife populations (Moen 1973, Robbins 1973, Bobeck 1977, Wallmo et al. 1977, Mautz 1978, Hobbs et al. 1982, Potvin and Huot 1982, Hobbs and Swift 1985). Traditional methods for estimating nutritional carrying capacity have been derived by dividing the range

The study was supported by the Caesar Kleberg Foundation for Wildlife Conservation.

Manuscript accepted 10 Mar. 1996 supply of dry matter, digestible energy, and digestible nitrogen by the product of an animal's daily requirements and the time period of interest, such as dormant season length (Wallmo et al. 1977, Hobbs et al. 1982, Potvin and Huot 1982). Hobbs and Swift (1985) developed an integrated approach for estimating carrying capacity using both forage quantity and quality. These techniques have been useful for comparing the relative productivity of plant communities and understanding the relationship between ungulates and environmental conditions (Wallmo et al. 1977, Hobbs et al. 1982, Potvin and Huot 1982, Hobbs and Swift 1985).

Estimating digestible energy consumed by tame deer is an alternative technique for determining nutritional carrying capacity (Clark 1977, Cowan and Clark 1981, Potts and Cowan 1983). Ullrey et al. $(1969,1970)$ first documented the relationship between digestible energy intake and rate of weight change of tame white-tailed deer. Clark (1977) used this relationship to estimate the nutritional carrying capacity for small enclosures using the rate of weight change, estimated digestible energy intake, number of trial days, encrgy requirements, and size of area. However, the tame-deer technique has not been critically evaluated, nor have the results been compared to traditional techniques.

We evaluated the use of digestible energy consumed by tame deer and traditional forage-based methods to estimate the nutritional carrying capacity of shrub communities for white-tailed deer. We defined nutritional carrying capacity as the maximum number of animals that can forage on a given plant community without weight loss for a given period of time. We compared the absolute and relative estimates of carrying capacity using the tame-deer technique to those based on traditional methods involving range supplies of dry matter, digestible energy, digestible nitrogen, dry matter*digestible energy, and dry matter*digestible nitrogen. We also compared the cost of each technique.

\section{Study Area}

We conducted the study on two 1-ha enclosures on the San Vicente Ranch, Hidalgo County, Tex. Cover in the north enclosure consisted of 2 plant communities: $27 \%$ in intervening $15-\mathrm{m}$ wide strips of shrubs and $73 \%$ in $122-\mathrm{m}$-wide roller-chopped areas. Shrubs were composed primarily of lime pricklyash (Zanthoxylum fagara Sarg.) with smaller percentages of brasil 
(Condalia hookeri M.C. Johnst.), honey mesquite (Prosopis glandulosa Torr.), and spiny hackberry (Celtis pallida Torr.). In the roller-chopped area, forbs and grasses were the main forage categories. Common forbs were onion (Allium sp.), partridge pea senna (Cassia fasciculata Buckl.), croton (Croton spp.), and gaillardia (Gaillardia sp.). Threeawn (Aristida spp.), buffle sandbur (Cenchrus ciliaris L.), and coast sandbur ( $C$. incertus M.A. Curtis) were the common grasses. The south enclosure consisted of a grass and shrub savannah community that was not manipulated by humans. Brasil and lime pricklyash were the primary shrubs in the south enclosure.

Weather is typical of semiarid areas. Summer temperatures are consistently $>32^{\circ} \mathrm{C}$. Annual precipitation at San Manuel, Tex. (8 $\mathrm{km}$ east of the study area), averages $680 \mathrm{~mm}$ (J. Chapa, unpubl. data, Natl. Oceanic and Atmos. Adm., San Manuel, 1987). Temperatures and precipitation were normal for the area during the study.

\section{Methods}

We determined carrying capacity during summer. In southern Texas, summers and winters can be stressful for deer because of lack of precipitation. Drought periods result in large weight loss of deer (Long et al. 1965, Fowler et al. 1967, Wheaton and Brown 1983) and sometimes large population losses (Teer 1984).

\section{Digestible Energy Consumed by Tame Deer}

In July 1987, we constructed two 1-ha electric fence enclosures on the ranch. We selected a 1-ha enclosure to ensure sufficient vegetation for $\geq 30$-day trials. At least this duration of trial is needed so deer lose weight slowly and steadily (e.g., $10 \mathrm{~g} \mathrm{~kg}^{-0.75}$ day $^{-1}$ ) (Potts and Cowan 1983) because deer on 0 or near 0 intake have a wide variation of weight loss among individuals (Hershberger 1984).

On 24 July we randomly placed four $2.5-4.5$-year-old tame does in each enclosure. All does used in the study produced fawns from 15 June to 7 July 1987 . We removed fawns from their mothers 2 days after birth. From weaning to the start of the trial, we fed deer a commercial pelleted feed containing $16 \%$ protein and $3.3 \mathrm{kcal} \mathrm{g}^{-1}$ of digestible energy. Deer also foraged on forbs, grasses, and brush for 60 days prior to the trial, which acclimated them to natural forage.

Prior to initial and final weighings, we withheld food from the deer for 24 hours to standardize rumen fill (Potts and Cowan 1983). Although the rumen requires $2-4$ days to completely empty, Potts and Cowan found this amount of time stresses the deer before trials.

We weighed deer with a portable platform scale at the beginning and end of each trial and once each week (Potts and Cowan 1983). We used the initial and final weights to determine their rate of weight change and the intermediate weights to assess weekly condition. We fed deer a small portion of pelleted feed to get them to voluntarily enter a crate mounted on the scale. This was the only supplemental feed they received during the trial. We subtracted the digestible energy supplied by the supplemental feed (approx. $3.3 \mathrm{kcal} \mathrm{g}^{-1}$ ) from the final results. We terminated trials when (1) visual condition of deer had declined significantly and (2) visual inspection of the enclosure showed little available forage.
We used the regression equation, $Y=0.0844 X-13.4\left(\mathrm{R}^{2}=\right.$ $0.96, \mathrm{MSE}=2.58$ ) to predict digestible energy intake for deer based on their rate of weight change (Clark, unpubl. data, Pennsylvania State Univ.). $Y$ is the rate of weight change per deer in $\mathrm{g} \mathrm{kg}^{-0.75}$ day ${ }^{-1}$ and $X$ is the digestible energy consumed $\mathrm{kg}^{-0.75}$ deer $^{-1}$ day $^{-1}$. Clark conducted feeding trials using 19 adult does, and trials took place during the winter. Clark fed deer on different levels of maintenance digestible energy and determined their rates of weight loss. This equation predicted that the maintenance level of digestible energy was $159 \mathrm{kcal} \mathrm{kg}^{-0.75}$ day $^{-1}$, which was consistent with other published values (Ullrey et al. 1969, 1970). We assumed that the regression equation developed by Clark (unpubl. data, Pennsylvania State Univ.) using penned does in winter in Pennsylvania accurately predicted the digestible energy consumed by deer in this study in summer. Summer is a period of weight loss for deer in Texas, and winter is a period of weight loss in Pennsylvania.

We also assumed the feeding behavior of tame and wild deer was similar (McMahan 1964, Watts 1964, Healy 1967, Wallmo and Neff 1970, Olson-Rutz and Urness 1987). In addition, for calculating estimates of carrying capacity, we assumed deer consumed a maintenance diet and lost no weight.

Knowledge of the precision of estimates of carrying capacity using the tame-deer technique is important. McCall (1988) determined the precision of the tame-deer technique using 3 adjacent 0.4-ha enclosures. Carrying capacity estimates for the 3 enclosures were $6.0(90 \% \mathrm{CI}=5.9-6.1)$ deer ha ${ }^{-1} 72$ days $^{-1}, 5.4(\mathrm{CI}=$ $5.2-5.7)$, and $5.3(\mathrm{CI}=5.1-5.4)$, respectively. Differences in carrying capacity estimates among enclosures were probably because of differences in usable forage. At the start of the trial, there was $730 \mathrm{~kg} \mathrm{ha}^{-1}$ of forage in enclosure 1,590 in enclosure 2 , and 450 in enclosure 3 . Six-hundred sixty $\mathrm{kg} \mathrm{ha}^{-1}$ of forage was consumed from enclosure 1, 550 from enclosure 2, and 630 from enclosure 3, which included production of forage during the trial.

\section{Forage Dry Matter, Digestible Energy, Digestible Nitrogen, Dry Matter*Digestible Energy, and Dry Matter*Digestible Nitrogen}

We estimated carrying capacity by dividing the total range supply of dry matter, digestible energy, and digestible nitrogen by the product of a deer's daily dry matter, digestible energy, and digestible nitrogen requirement and the trial days. In addition, we estimated carrying capacity by integrating dry matter and digestible energy, and dry matter and digestible nitrogen (Hobbs and Swift 1985). Quantifying range supplies of each nutrient required an assessment of usable amounts of principal deer foods. We determined principal deer foods by (1) recording bite-count data from the tame deer in the enclosures (Whelan et al. 1971) and (2) microhistological analysis of rumen contents of 8 wild deer collected during September on the ranch (Gray et al. 1980). Principal deer foods were those that made up $\geq 5 \%$ of deer diets during the trial. We determined usable forage by the difference between the biomass of principal browse, forbs, and grasses at the beginning (27 July) and end of the trial (22-24 September).

Before the trial, we determined biomass of forage using a double-sampling technique because it was non-destructive to the vegetation in the enclosures (Scanlon and Sharik 1986). In each enclosure we randomly selected twenty $0.25-\mathrm{m}^{2}$ plots. On each plot we made ocular estimates of cover to a height of $180 \mathrm{~cm}$ above ground, against a 50-x 50-cm screen. Outside the enclo- 
sures, we estimated cover on 60 additional plots ( $n=30$ north, $n$ $=30$ south) from 27 July to 5 August 1987 . We clipped all of the outside plots and developed regression equations for each major plant type (forb, grass, brasil, honey mesquite, lime pricklyash, spiny hackberry) to estimate the biomass of available forage on unclipped plots within the enclosures. We oven dried forage from all plots by plant type at $40^{\circ} \mathrm{C}$ for 2 weeks and weighed to the nearest $0.1 \mathrm{~g}$. At the end of the trial, we clipped thirty $0.25-\mathrm{m}^{2}$ plots from each plant community ( 2 north enclosure, 1 south enclosure) within each enclosure to determine the biomass of forage remaining. To calculate total dry matter of usable forage in each enclosure, we summed mean values for principal forages.

We collected three 50 -g samples of principal forbs, grasses, and the 4 shrub species from 5 to 7 August 1987, for analysis of digestible energy and digestible nitrogen. We dried samples at $40^{\circ} \mathrm{C}$ for 2 weeks and analyzed for dry matter, ash, in vitro digestibility of organic matter (IVDOM) (Tilley and Terry 1963), and nitrogen content (Assoc. Off. Anal. Chem. 1970). We determined IVDOM using rumen inoculum from a fistulated Jersey cow fed alfalfa (Medicago sativa) hay. We calculated digestible energy for IVDOM using the formula of Bryant et al. (1981) modified for use with IVDOM.

Assumptions are inherent in the forage-based techniques. For the digestible nitrogen-based estimate, researchers may not select forage samples as high in nitrogen as those selected by ungulates (Swift 1948, Wier and Torrell 1959, Longhurst et al. 1968). Researchers are also uncertain how animals mix the various forages in their diet to balance their requirements (Hobbs and Swift 1985). Furthermore, it is assumed that ungulates select forages with the highest energy and nitrogen content, but secondary plant compounds of forage also may influence diet selection and digestibility (Bryant and Kuropat 1980). Additionally, energy and nitrogen requirements derived from penned animals may not be accurate for wild ungulates. Finally, weather may change the supply of available forage daily making forage quantity and quality difficult to assess (Potvin and Huot 1982, McCall 1988).

\section{Data Analysis}

We used Cowan and Clark's (1981) technique and equations to estimate nutritional carrying capacity for the enclosures using digestible energy consumed by tame deer. We calculated the digestible energy consumed per deer during the trial by multiplying the digestible energy consumed per day per deer by the number of trial days and the deer's metabolic weight $\left(\mathrm{kg}^{0.75}\right)$. We determined the total digestible energy consumed by all deer in the enclosure by summing the digestible energy consumed per deer. We then calculated estimates of carrying capacity for each enclosure by dividing the total digestible energy consumed by the deer in the enclosure by the product of the deer's daily digestible energy requirement ( $159 \mathrm{kcal} \mathrm{kg}^{-0.75} \mathrm{day}^{-1}$ ) and the trial length (58 days). We reported carrying capacity as deer per ha per trial days.

We calculated estimates of carrying capacity using dry matter by dividing the total range supply of dry matter by the product of the deer's daily intake of dry matter (mean intake of dry matter from the 2 enclosures) and the trial length. We calculated the mean daily intake per enclosure by dividing the total dry matter of useable forage per enclosure by the product of the number of deer per enclosure and the trial length. Carrying capacity estimates using digestible energy were calculated by dividing the total range supply of digestible energy by the product of the deer's daily digestible energy requirement ( $159 \mathrm{kcal} \mathrm{kg}^{-0.75}$ day $\left.^{-1}\right)$, the mean metabolic weight of deer per enclosure, and the trial length. We calculated total range supply of digestible energy as the sum of the products of usable dry matter of forage values and their digestible energy content.

We determined digestible nitrogen-based estimates of carrying capacity by dividing total forage supply of nitrogen by the product of each deer's daily requirement $\left(0.77 \mathrm{~g} \mathrm{~N} \mathrm{~kg}^{-0.75}\right.$ day $\left.^{-1}\right)$ (Holter et al. 1979), the mean metabolic weight of a deer per enclosure, and trial length (58 days). Total plant community supply of nitrogen was calculated by summing the products of usable forage dry matter values for each category or species and their nitrogen values. True digestible nitrogen was estimated by multiplying the total $N$ supply by 0.90 (Robbins 1973:Table 26).

We followed Hobbs and Swift's (1985) methods for estimating carrying capacity based on combining dry matter and digestible energy, and dry matter and digestible nitrogen of forage. We assumed a diet quality level for maintenance of digestible energy of $159 \mathrm{kcal} \mathrm{kg}^{-0.75} \mathrm{day}^{1}$, and of digestible nitrogen of $1.3 \mathrm{~g} \mathrm{~N} 100$ $\mathrm{g}^{-1}$ dry matter. We did not separate plant parts of the same plant species for determining nutritional quality.

We calculated approximate $90 \%$ confidence intervals for estimates of carrying capacity using bootstrap approximations (Sprent 1989). We drew 1,000 subsamples from each nutritional parameter of forage with replacement. We used subsamples to calculate 1,000 iterations of the carrying capacity equations. For the tame-deer technique, variance associated with the estimated intake of digestible energy and the variance related to weekly weights of deer were used to develop confidence intervals. We did not include the variance in weight loss among deer within the same enclosure because these weights were not independent from each other due to dominance hierarchy that was observed among deer (McCall 1988). For the dry matter, digestible energy, digestible nitrogen, dry matter*digestible energy, and dry matter*digestible nitrogen-based techniques, variances associated with the mean estimate of dry matter for each forage type were included. Approximate confidence intervals were determined by excluding the extreme $1 / 2 \mathrm{~N} \propto$ values from the ranked carrying capacity iterations (Sprent 1989). One thousand iterations were calculated to achieve sufficient sample size for testing (Efron and Tibshirani 1993).

\section{Cost of Techniques}

We compared the cost (labor and materials) of each technique for estimating carrying capacity. We assumed a minimum wage of $\$ 4.90$ hour $^{-1}$ for labor costs. We did not include the expense of raising the deer and housing them while the trials were not in progress in our cost comparison because deer could be used for other projects during this time.

\section{Results}

Estimated carrying capacity ranged from 3.5-15.2 deer ha ${ }^{-1} 58$ days $^{-1}$ in the north enclosure and 2.1-10.1 deer ha ${ }^{-1} 58$ days $^{-1}$ in the south enclosure (Table 1). Estimates using digestible energy of tame deer, dry matter*digestible energy, and dry matter*digestible nitrogen did not differ within an enclosure. Estimates using forage digestible energy and digestible nitrogen differed from each other and all of the other techniques. The 
Table 1. Comparison of nutritional carrying capacity estimates (deer ha ${ }^{-1}$ 58 days $^{-1}$ ) using digestible energy (DE) consumed by tame deer, and forage dry matter (DM), DE, digestible nitrogen (DN), DM*DE, and $D^{*} D N$ for the north and south 1-ha enclosures on the San Vicente Ranch, Hidalgo County, Tex., 24 July to 19 September 1987.

\begin{tabular}{|c|c|c|c|c|}
\hline \multirow[b]{2}{*}{ Technique } & \multicolumn{2}{|c|}{ North } & \multicolumn{2}{|c|}{ South } \\
\hline & Estimate & $\mathrm{CI}^{1}$ & Estimate & $\mathrm{CI}$ \\
\hline & \multicolumn{4}{|c|}{ 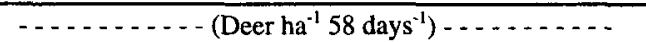 } \\
\hline DF tame deer & $3.65 \mathrm{Aa}^{2}$ & $3.61-3.69$ & $2.6 \mathrm{Ab}$ & $2.5-2.7$ \\
\hline DM forage & $4.5 \mathrm{Ba}$ & $3.7-5.3$ & $3.5 \mathrm{Ba}$ & $3.2-3.9$ \\
\hline DE forage & $9.4 \mathrm{Ca}$ & $7.3-11.5$ & $6.8 \mathrm{Ca}$ & $6.0-7.6$ \\
\hline DN forage & $15.2 \mathrm{Da}$ & $11.6-18.8$ & $10.1 \mathrm{Db}$ & $8.8-11.3$ \\
\hline $\mathrm{DM}^{*} \mathrm{DE}$ forage & $3.5 \mathrm{ABa}$ & $2.7-4.3$ & $2.1 \mathrm{Ab}$ & $1.8-2.6$ \\
\hline $\mathrm{DM}{ }^{*} \mathrm{~N}$ forage & $3.5 \mathrm{ABa}$ & $2.7-4.3$ & $2.8 \mathrm{Aa}$ & $2.4-3.1$ \\
\hline
\end{tabular}

${ }_{1} \mathrm{CI}=$ Confidence Interval.

${ }^{2}$ Means within the same column sharing the same upper case letter do not differ $(\mathrm{P}<0.10)$; means within a row with the same lower case letter do not differ $(\mathrm{P}<0.10)$.

average daily dry matter intake for the 2 enclosures was $2.06 \mathrm{~kg}$ deer $^{-1}$ day $^{-1}$. The tame-deer trial lasted 58 days, from 24 July to 19 September 1987.

Estimates of total digestible energy consumed by deer using the tame-deer technique in the north enclosure $(560,960 \mathrm{kcal})$ was greater than in the south enclosure $(404,630 \mathrm{kcal})$ (Table 2$)$. Estimates of usable dry matter, digestible energy, and digestible nitrogen were higher for the north $\left(540 \mathrm{~kg}\right.$ dry matter ha ${ }^{-1}$, $1,447,410 \mathrm{kcal}$ digestible energy ha ${ }^{-1}, 11.3 \mathrm{~kg}$ digestible nitrogen $\mathrm{ha}^{-1}$ ) than the south enclosure (420 kg dry matter ha $\mathrm{kg}^{-1}, 1,042,290$ kcal digestible energy ha ${ }^{-1}, 7.5 \mathrm{~kg}$ digestible nitrogen $\mathrm{ha}^{-1}$ ). Consequently, all estimates of carrying capacity were higher for the north than south enclosure. Estimates (digestible energy from tame deer, dry matter forage, digestible energy forage, digestible nitrogen of forage, dry matter*digestible energy, dry matter*digestible nitrogen) were $1.4,1.3,1.4,1.5,1.6$, and 1.3 times greater, respectively, for the north than the south enclosure; however, only digestible energy of tame deer, digestible nitrogen, and dry matter*digestible energy differed statistically $(\mathrm{P}<0.10)$.

Estimates of carrying capacity using the tame-deer technique $\left(\$ 2,820\right.$ enclosure $\left.^{-1}\right)$ were 8 times more costly than using the dry matter-based technique ( 80 plots at $\$ 4.38$ plot $^{-1}=\$ 350$ ), 7 times more costly than using digestible energy from forage ( 80 plots at $\$ 5.00$ plot $^{-1}=\$ 400$ ), and 6 times more costly than the digestible nitrogen-based technique (80 plots at $\$ 5.63$ plot $^{-1}=\$ 450$ ). There were no additional costs for running the dry matter*digestible energy and dry matter*digestible nitrogen-based techniques than for treating the nutrients separately. Thirty-four percent of the cost for the tame-deer technique was for labor and $66 \%$ for materials. Fencing accounted for $70 \%$ of the materials costs; however, fencing could be amortized over several trials. Enclosures required 20.6 days enclosure ${ }^{-1}$ to construct and 4.4 days enclosure $^{-1}$ to remove ( 1 day $=8$ hours).

\section{Discussion}

Although some of the absolute estimates of nutritional carrying capacity differed, each technique provided a similar index to the relative carrying capacity of the north versus the south enclosure (carrying capacity north/carrying capacity south $=1.3-1.6$ ). Greater forage supplies of dry matter, digestible energy, and digestible nitrogen on the north resulted in the higher estimates of carrying capacity relative to the south.

For the north enclosure, estimates of carrying capacity using dry matter, dry matter*digestible energy, and dry matter*digestible nitrogen of forage were the same because digestible energy and digestible nitrogen concentrations of all forages were greater than or equal to the critical dietary levels. Estimates using dry matter and dry matter*digestible nitrogen were also the same for the south enclosure as digestible nitrogen concentrations also exceeded critical levels. However, the digestible energy value of 1 forage species in the south enclosure resulted in only $50 \%$ of it being usable before digestible energy for all forages fell below critical levels. Thus, not all the forage was nutritionally useful to deer (Hobbs and Swift 1985) in the south enclosure, resulting in a carrying capacity estimate for dry matter*digestible energy that was lower than for dry matter.

Confidence intervals for estimates of carrying capacity using dry matter, digestible energy, digestible nitrogen, dry matter*digestible energy, and dry matter*digestible nitrogen of forage, were higher than those from the tame-deer technique because of the high variance associated with the double-sampling technique used to estimate usable forage. Traditional estimates of carrying capacity using digestible energy and digestible nitrogen normally involve clipping a sample of plots (Hobbs et al. 1982), which would probably result in lower confidence intervals.

Despite its assumptions, the tame-deer technique appears to be a valid method for estimating relative carrying capacity as it produced similar results to those of the forage-based estimates. The

Table 2. Nutritional carrying capacity data and calculations using estimated digestible energy (DE) consumed by tame deer from the north (N) and south (S) 1-ha enclosures on the San Vicente Ranch, Hidalgo County, Tex., from 24 July to 19 September 1987.

\begin{tabular}{|c|c|c|c|c|c|c|c|c|c|c|c|c|}
\hline \multirow{2}{*}{\multicolumn{2}{|c|}{$\begin{array}{l}\text { Enc.', } \\
\text { Deer \# }\end{array}$}} & \multicolumn{2}{|c|}{ Weight } & \multirow{2}{*}{$\begin{array}{l}\text { Avg. } \\
\text { MWT }^{2}\end{array}$} & \multirow{2}{*}{$\begin{array}{c}\text { Wt. } \\
\text { Change }\end{array}$} & \multirow{2}{*}{$\begin{array}{l}\text { Mean Wt. } \\
\text { Change }\end{array}$} & \multirow[b]{2}{*}{$\mathrm{Y}^{3}$} & \multirow[b]{2}{*}{$\mathbf{X}^{4}$} & \multirow{2}{*}{$\begin{array}{l}\text { Total DE } \\
\text { Intake }\end{array}$} & \multirow{2}{*}{$\begin{array}{l}\text { Supp. } \\
\text { Feed }^{5}\end{array}$} & \multirow{2}{*}{$\begin{array}{c}\text { Net DE } \\
\text { Intake }^{6}\end{array}$} & \multirow{2}{*}{$\begin{array}{c}\text { Total DE } \\
\text { Enc. }\end{array}$} \\
\hline & & Begin & End & & & & & & & & & \\
\hline & & \multicolumn{2}{|c|}{$\ldots-\ldots(\mathrm{kg}) \ldots$} & \multicolumn{2}{|c|}{$\ldots \ldots(\mathrm{kg})-\ldots$} & \multicolumn{3}{|c|}{$--\left(\mathrm{g} \mathrm{day}^{-1}\right)--$} & \multicolumn{4}{|c|}{$\ldots \ldots \ldots \ldots$ (kcal) $\ldots \ldots \ldots \ldots$} \\
\hline \multirow[t]{4}{*}{$\mathbf{N}$} & 1 & 45.4 & 44.2 & 17.3 & -1.1 & -19.6 & -1.1 & 145.4 & 146,000 & 2,300 & 143,710 & \\
\hline & 2 & 47.0 & 43.8 & 17.5 & -3.2 & -54.7 & -3.1 & 121.7 & 123,330 & 2,850 & 120,480 & 560,960 \\
\hline & 3 & 44.7 & 44.7 & 17.3 & 0.0 & 0.0 & 0.0 & 158.8 & 159,140 & 980 & 158,160 & \\
\hline & 4 & 44.2 & 42.9 & 17.0 & -1.4 & -23.5 & -1.4 & 142.4 & 139,970 & 1,360 & 138,610 & \\
\hline \multirow[t]{4}{*}{$S$} & 5 & 39.7 & 36.5 & 15.3 & -3.2 & -54.7 & -3.6 & 116.5 & 103,600 & 2,130 & 101,470 & \\
\hline & 6 & 41.3 & 37.9 & 15.8 & -3.4 & -58.7 & -3.7 & 114.7 & 104,990 & 1,020 & 103,970 & 404,630 \\
\hline & 7 & 43.1 & 41.3 & 16.6 & -1.8 & -31.3 & -1.9 & 136.4 & 130,930 & 0 & 130,930 & \\
\hline & 8 & 40.6 & 34.7 & 15.2 & -5.9 & 101.7 & -6.7 & 79.5 & 79,090 & 1,830 & 68,260 & \\
\hline
\end{tabular}


tame-deer technique has advantages and disadvantages relative to Hobbs and Swift's (1985) technique. As in Hobbs and Swift's technique, the tame-deer method integrates diet quality and food quantity, which facilitates decisions on stocking densities of herbivores. The advantage of the tame-deer technique is that it relates forage consumed to weight change of animals. Thus, there is no need to predict how deer mix forages containing different concentrations of digestible energy in their diet to balance energy needs, nor is it necessary to know how digestible energy is distributed within the available forage. In addition, it is not necessary to assume deer select higher quality forage items in preference to lower quality ones. A disadvantage of the tame-deer method is that it assumes regression equations from penned deer reflect the digestible energy consumed by animals in enclosures. The primary disadvantage of the tame-deer method is that it is costly $\left(\$ 2,8001\right.$-ha enclosure $\left.{ }^{-1}\right)$ to construct a large number of enclosures to sufficiently sample variable plant communities. Forage-based estimates of carrying capacity are less expensive, which enable managers to increase sample sizes, thus better account for the variability within and among plant communities. However, many physiological and behavioral characteristics of free-ranging deer make it difficult to estimate the exact number of animals that can be supported on a range.

To improve the precision of estimates of carrying capacity using the tame-deer technique, specific criteria should be used to decide when to terminate trials. We ended trials when visual condition of deer deteriorated significantly and visual inspection of the enclosure indicated little available forage. However, we suggest ending trials when the average weight of deer drops by $15.0 \%$, or some other specific amount, which provides more objective criteria for stopping trials. The accuracy of estimates may be improved by developing a regression equation to predict digestible energy consumed from rate of weight loss using penned does from the region of the country and the season of the year in question.

Because all the assumptions inherent in each carrying capacity technique are unlikely to be met, absolute measures of carrying capacity are questionable. Therefore, we believe the value of carrying capacity estimates lies in relative comparisons of sites. Although some methods for estimating carrying capacity provided different absolute results in our study, all produced similar relative estimates between enclosures. Therefore, we believe any of the methods can be used to determine the relative nutritional quality of different plant communities. However, we recommend using supplies of forage dry matter to estimate carrying capacity as it was the least expensive technique for sampling variable plant communities and provided similar relative results to the other techniques. Hobbs and Swift's (1985) technique may be more useful than the other forage-based techniques for estimating the relative stocking rates of deer where forage quality differs greatly among areas, such as between burned and unburned areas. However, in our study forage quality was greater than minimum requirements for all forage species, except one, making calculation of the Hobbs and Swift technique unnecessary. Future studies should estimate carrying capacity using all of the forage-based techniques used in this study. If these results indicate that digestible energy, digestible nitrogen, dry matter*digestible energy, and dry matter*digestible nitrogen estimates of carrying capacity are relatively similar to dry matter estimates, then dry matter alone should be used.

\section{Literature Cited}

Association of Official Analytical Chemists. 1970. Official methods of analysis. 11th ed. Assoc. Off. Anal. Chem., Washington, D.C.

Bobeck, B. 1977. Summer food as the factor limiting roe deer population size. Nature 268:47-49.

Bryant, J.P. and P.J. Kuropat. 1980. Selection of winter forage by subarctic browsing vertebrates: the role of plant chemistry. Annu. Rev. Ecol. Syst. II:261-285.

Bryant, F.C., C.A. Taylor, and L.B. Merrill. 1981. White-tailed deer diets from pastures in excellent and poor range condition. J. Range. Manage. 34:193-200.

Clark, A.C. 1977. Nutrient intake of white-tailed deer in winter and determination of the feeding capacity of deer range. Ph.D. Thesis, Pennsylvania State Univ., University Park, Penn.

Cowan, R.L. and A.C. Clark. 1981. Nutritional requirements, p. 72-86. In: Diseases and parasites of white-tailed deer. Tall Timbers Res. Sta. Misc. Publ. 7, Tallahassee, Fla.

Efron, B. and R.J. Tibshirani. 1993. An introduction to the bootstrap. Chapman and Hall. N.Y.

Fowler, J.F., J.D. Newson, and H.L. Short. 1967. Seasonal variation in food consumption and weight gain in male and female white-tailed deer, p. 24-32. In: Proc. Southeast. Assoc. Game and Fish Comm.

Gray, M.H., G.K. Yarrow, and H.A. Jacobson. 1980. Comparison of three deer rumen content identification techniques. Southeast Deer Study Group Meeting, Nacogdoches, Tex.

Healy, W.M. 1967. Forage preferences of captive deer while free ranging in the Allegheny National Forest. M.S. Thesis, Pennsylvania State Univ., University Park, Penn.

Hershberger, T.V. (ed.) 1984. The effects of fasting and refeeding on white-tailed deer. The Pennsylvania State Univ. Bull. No. 846. University Park, Penn.

Hobbs, N.T. and D.M. Swift. 1985. Estimates of habitat carrying capacity incorporating explicit nutritional constraints. J. Wildl. Manage. 49:814-822.

Hobbs, N.T., D.L. Baker, J.E. Ellis, D.M. Swift, and R.A. Green. 1982. Energy and nitrogen-based estimates of elk winter-range carrying capacity. J. Wildl. Manage. 46:12-21.

Holter, J.B., H.H. Hayes, and S.H. Smith. 1979. Protein requirements of yearling white-tailed deer. J. Wildl. Manage. 43:872-879.

Long, T.A., R.L. Cowan, G.D. Strawn, R.S. Wetzel, and R.C. Miller. 1965. Seasonal fluctuations in feed consumption of the white-tailed deer. Penn. Agric. Exp. Stn. Bull. 262. University Park, Penn.

Longhurst, W.M., H.K. Oh, M.B. Jones, and R.E. Kepner. 1968. A basis for the palatability of deer forage plants. Trans. North Amer. Wildl. Nat. Resour. Conf. 33:181-189.

Mautz, W.W. 1978. Nutrition and carrying capacity, p. 321-348. In: J.L. Schmidt and D.L. Gilbert (eds.), Big Game of North America. Stackpole Books, Harrisburg, Penn.

McCall, T.C. 1988. Comparison of tame-deer enclosures and forage analyses for determining the carrying capacity of white-tailed deer. M.S. Thesis, Texas A\&M Univ., Kingsville, Tex.

McMahan, C.A. 1964. Comparative food habits of deer and three classes of livestock. J. Wildl. Manage. 32:142-148.

Moen, A.N. 1973. Wildlife ecology, an analytical approach. W.H. Freeman and Co., San Francisco, Calif.

Olson-Rutz, K.M. and P.J. Urness. 1987. Comparability of foraging behavior and diet selection of tractable and wild mule deer. Publ. 88-3. Ut. Div. Wildl. Resour., Salt Lake City, Utah.

Potts, R.R. and R.L. Cowan. 1983. Evaluation of dormant season feeding capacity of deer habitats from digestible energy intake estimates. Dep. Dairy and Anim. Sci., Pennsylvania State Univ., University Park, Penn.

Potvin, F. and J. Huot. 1982. Estimating carrying capacity of a whitetailed deer wintering area in Quebec. J. Wildl. Manage. 47:463-475.

Robbins, C.T. 1973. The biological basis for the determination of carrying capacity. Ph.D. Thesis, Cornell Univ., Ithaca, N.Y. 
Scanlon, J.J. and T.L. Sharik. 1986. Forage energy for white-tailed deer in loblolly pine plantations. J. Wildl. Manage. 50:301-306.

Sprent, P. 1989. Applied nonparametric statistical methods. Chapman and Hall, London.

Swift, R.W. 1948. Deer select most nutritious forage. J. Wildl. Manage. 12:109-110.

Teer, J.G. 1984. Lessons from the Llano Basin, Texas, p. 261-290. In: L.K. Halls (ed.), White-tailed deer. Stackpole Books, Harrisburg, Penn.

Tilley, J.M.A. and R.A. Terry. 1963. A two-stage technique for the in vitro digestion of forage crops. J. Br. Grassl. Soc. 18:104-111.

Ullrey, D.E., W.G. Youatt, H.E. Johnson, L.D. Fay, B.L. Schoepke, and W.T. Magee. 1969. Digestible energy requirements for winter maintenance of Michigan white-tailed does. J. Wildl. Manage. $33: 482-490$.

Ullrey, D.E., W.G. Youatt, H.E. Johnson, L.D. Fay, B.L. Schoepke, and W.T. Magee. 1970. Digestible and metabolizable energy requirements for winter maintenance of Michigan white-tailed does. J. Wildl. Manage. 34:863-869.
Wallmo, O.C. and D.J. Neff. 1970. Direct observations of tamed deer to measure their consumption of natural forage, p. 105-110. In: Range and Wildlife Habitat Evaluation - A Research Symposium. USDA. For. Serv. Misc. Publ. 1147.

Wallmo, O.C., L.H. Carpenter, W.L. Regelin, R.B. Gill, and D.L. Baker. 1977. Evaluation of deer habitat on a nutritional basis. J. Range Manage. 30:122-127.

Watts, C.R. 1964. Forage preferences of captive deer while free ranging in a mixed oak forest. M.S. Thesis, Pennsylvania State Univ. University Park, Penn.

Wheaton, C. and R.D. Brown. 1983. Feed intake and digestive efficiency of south Texas white-tailed deer. J. Wildl. Manage. 47:442-450.

Whelan, J.B., R.F. Harlow, and H.S. Crawford. 1971. Selectivity, quality, and in vitro digestibility of decr foods: altcrnative model. Trans. Northeast. Fish and Wildl. Conf., Northeast. Sect. The Wildl. Soc. 28:67-81.

Wier, W.C. and D.T. Torrell. 1959. Selective grazing by sheep as shown by a comparison of the chemical composition of range and pasture forage obtained by hand-clipping and that collected by esophageal fistulated sheep. J. Anim. Sci. 18:641-649. 